\title{
DEPOSITIONAL REGIME OF THE KATABATIC SLOPE FROM MIZUHO PLATEAU TO THE COAST, EAST ANTARCTICA
}

\author{
by
}

Okitsugu Watanabe and Yoshiyuki Fujii

(National Institute of Polar Research, 9-10, Kaga 1-Chome, Itabashi-ku, Tokyo 173, Japan)

and

Kazuhide Satow

(Nagaoka College of Technology, Nagaoka, Japan)

\section{ABSTRACT}

Recently, a $700 \mathrm{~m}$ long ice core was drilled at Mizuho Station $(2230 \mathrm{~m}$ a.s.1.), $270 \mathrm{~km}$ south-east of Syowa Station and situated in a typical katabatic-slope region.

In order to obtain basic knowledge for dating the core and for interpreting climatic change and depositional environment change along the core, a study of the regional characteristics of the snow-deposition regime on Mizuho plateau has started. Surface-firn cores $10-30 \mathrm{~m}$ deep and snow-stake data obtained along the traverse routes on Mizuho plateau since 1970 were analyzed.

The general trend of annual snow accumulation and the regional characteristics of the $\delta^{18} \mathrm{O}$ profile of snow cover were obtained.

\section{INTRODUCTION}

The regional depositional regime under present climatic conditions was studied on the katabatic slope between the coast and Mizuho plateau. The results are relevant to the climatic change which is reflected in a $700 \mathrm{~m}$ long ice core taken at Mizuho Station $\left(70^{\circ} 42^{\prime} \mathrm{S}, 44^{\circ} 20^{\prime} \mathrm{E} ; 2230 \mathrm{~m}\right.$ a.s.1.) in 1984. In general, a great variety of parameters can be obtained from an ice core, and it is not a priori clear which is most descriptive of the depositional regime. Our first and tentative choice was annual net accumulation and oxygen-isotope distribution in the surface-snow layer. Various data on annual net accumulation obtained along traverse routes after 1968, and oxygen-isotope profiles obtained from shallow-pit studies and surface-snow cores at various places on Mizuho plateau were analyzed.

The observed variations in oxygen-isotope distribution may be due to temperature change during precipitation, to sea-ice formation off the coast, or to other causes. Special attention will be given to the separation of these effects.

The study area on Mizuho plateau, the location of observations, and the traverse routes are shown in Figure 1 .

REGIONAL TREND OF ANNUAL SNOW ACCUMULATION ON MIZUHO PLATEAU

The distribution of average annual net accumulation, measured by the single-stake method at $2 \mathrm{~km}$ intervals along the traverse routes (routes $\mathrm{S}, \mathrm{H}, \mathrm{Z}$, and $\mathrm{Y}$ between 550 and $2880 \mathrm{~m}$ a.s.1.) is shown in Figure $2 \mathrm{a}$ and b. The time intervals for snow-stake observation were different along each route: the longest (S18-S30) was from 1968 to 1983 , the shortest (Mizuho Station-Y200 and Mizuho Station-Advance Camp) was 1 year of observations, and the remainder ( $\mathrm{Hl}$-Mizuho Station) were observed from 1972 to 1983. The data are given in terms of snow depth, hence there will be systematic differences between observations made over different time spans.

As indicated by the heavy line in Figure 2a, 10 data https://doi.org/10.3189/S0260305500004419 Published online by Cambridge University Press

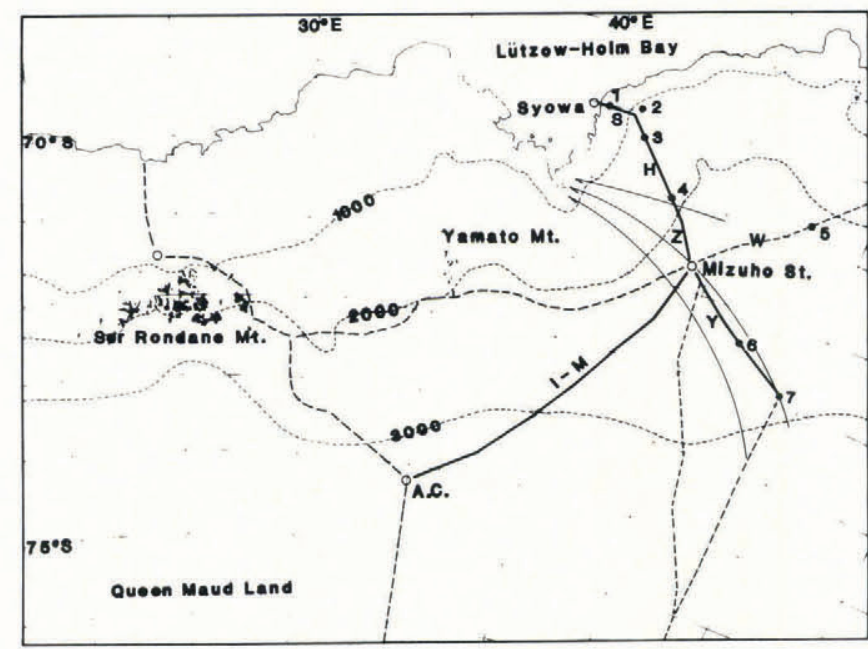

Fig.1. Map of the study area, Mizuho plateau, East Antarctica. Site no. 1: S18 (618 m a.s.1.); 2: S40 (1142 m); 3: H128 (1380 m); 4: S122 (1910 m); 5: W200 (2168 m); 6: Y100 $(2606 \mathrm{~m}) ; 7$ : Y200 $(2880 \mathrm{~m}) . \mathrm{S}, \mathrm{H}, \mathrm{Z}, \mathrm{Y}, \mathrm{W}$, and I-M: traverse routes; A.C.: Advance Camp. Long arrow lines show estimated flow lines.

running means of annual net accumulation are higher $(0.4-0.8 \mathrm{~m}$ snow per year) near the coast (and as far as about $160 \mathrm{~km}$ from the coast), due to the influence of low-pressure systems, and they decrease inland.

In Figure $2,+$ indicates the 4 year $(1971-74)$ average annual net accumulation along route W; a tendency for values to increase eastward from Mizuho Station is found.

Annual net accumulation and autumn-winter accumulation in 1985 along route $\mathrm{I}-\mathrm{M}$ between Mizuho Station and Advance Camp ( $74^{\circ} 12^{\prime} \mathrm{S}, 34^{\circ} 59^{\prime} \mathrm{E} ; 3193 \mathrm{~m}$ a.s.1.) are shown in Figure $2 \mathrm{~b}$. This shows a large-scale wave-like regional variation in annual net accumulation along the route, running perpendicularly to route $\mathrm{Y}$ from 2000 to $3000 \mathrm{~m}$ a.s.l.

\section{REGIONAL CHARACTERISTICS OF OXYGEN-ISOTOPE PROFILES}

Oxygen-isotope profiles of cores obtained from $10 \mathrm{~m}$ depth at various places on the katabatic slope are shown in Figure 3. These profiles are divided into two groups: (i) profiles obtained near the coast (Fig.3a) and (ii) profiles obtained from a typical katabatic-slope region (Fig.3b). 

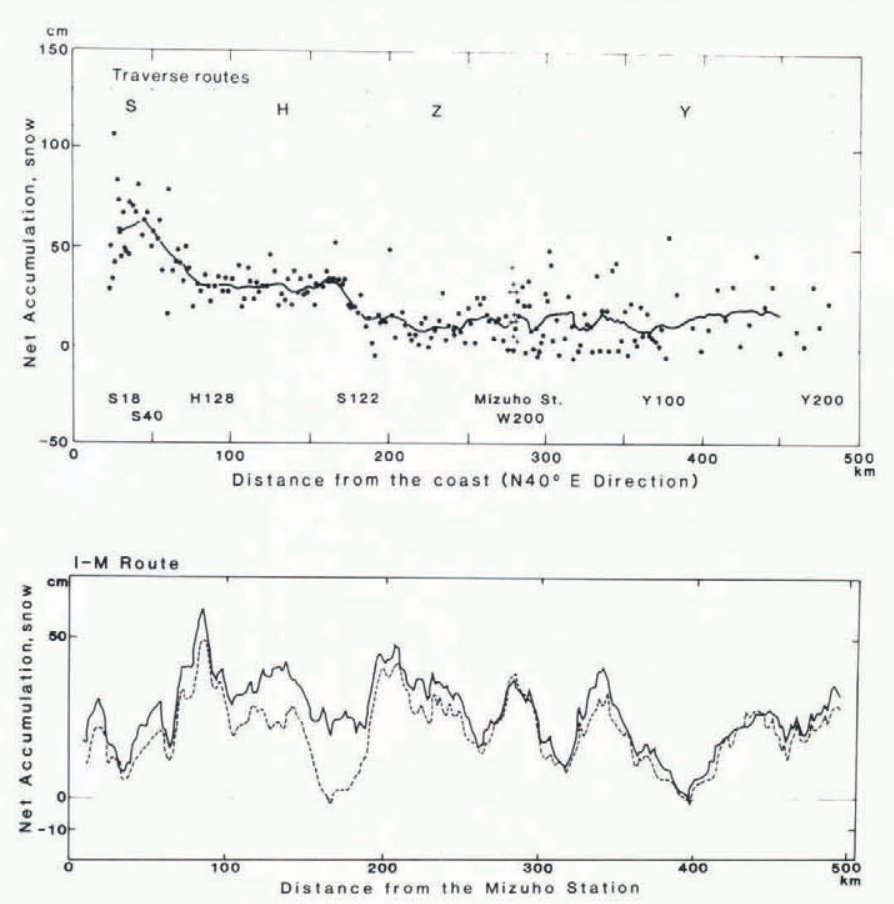

Fig.2. (a) Average annual net accumulation along the traverse routes on Mizuho plateau. +: data along route W. The heavy line shows the 10 point running mean. (b) Annual net accumulation January 1985-January 1986 (solid line), and autumn-winter accumulation January-September 1985 (broken line).

Large differences in depositional regime, such as the accumulation rate, the deposition-erosion process, and snow metamorphism between these two regions, were found as reported previously (Watanabe 1978[a], Satow and Watanabe 1985). W200 (station 5 in Fig.1) is $300 \mathrm{~km}$ from the coast. According to the $2 \mathrm{~m}$ pit study (Watanabe 1978[b]), the area surrounding $\mathrm{W} 200$ is a higher-accumulation area, as shown in Figure 2a, due to the topographic effect.
A comparison with stratigraphic observations shows that isotope profiles in group (i) exhibit typical seasonal variation, which provides a useful method of determining annual layers.

On the other hand, profiles in group (ii) show some irregular cycles, with larger (less negative deviation) values. In comparison with stratigraphic observations from $10 \mathrm{~m}$ cores, it can be seen, for instance, that in profile Y200, these larger values coincide with layers which have highly developed depth hoar. This indicates that secondary change in the isotope value after deposition plays an important role and characterizes isotope profiles in the surface-snow layers of a typical katabatic slope.

Inland, above $1700-2000 \mathrm{~m}$ on the Mizuho plateau, the mean annual snow accumulation rapidly decreases, and stationary katabatic winds, which are sufficiently strong to generate snow-drift forming patch-like snow deposits, are well developed (Shimizu and others 1978). As a result, the horizontal extent of annual layers is limited, and usually complete annual layers can be missing from the sequence. Due to the hiatus in serial deposition, depth-hoar formation occasionally develops in this region.

\section{DEPOSITIONAL REGIME OF THE REGION, RELATED TO THE MIZUHO $700 \mathrm{~m}$ LONG CORE}

As indicated by arrows in Figure 1 , the flow line of the ice sheet through Mizuho Station was estimated to be along route $\mathrm{Y}$, on the basis of observations made during the 1968-78 glaciological research program (Naruse and Shimizu 1978). The flow lines of the ice sheet were determined by using ice-flow vector data and surface-elevation contours.

As a natural consequence, the Mizuho $700 \mathrm{~m}$ long ice core represents snow layers which have been deposited on the flow line passing through Mizuho Station during the past several thousand years or more.

As basic information for interpretation of the core, the following factors on the depositional regime of this region along the flow line are discussed:

\section{Annual accumulation rate}

As seen in Figure 2a, the average annual accumulation on the katabatic slope decreases abruptly at a boundary which is $160-180 \mathrm{~km}$ from the coast, at $1700-1800 \mathrm{~m}$ a.s.1.
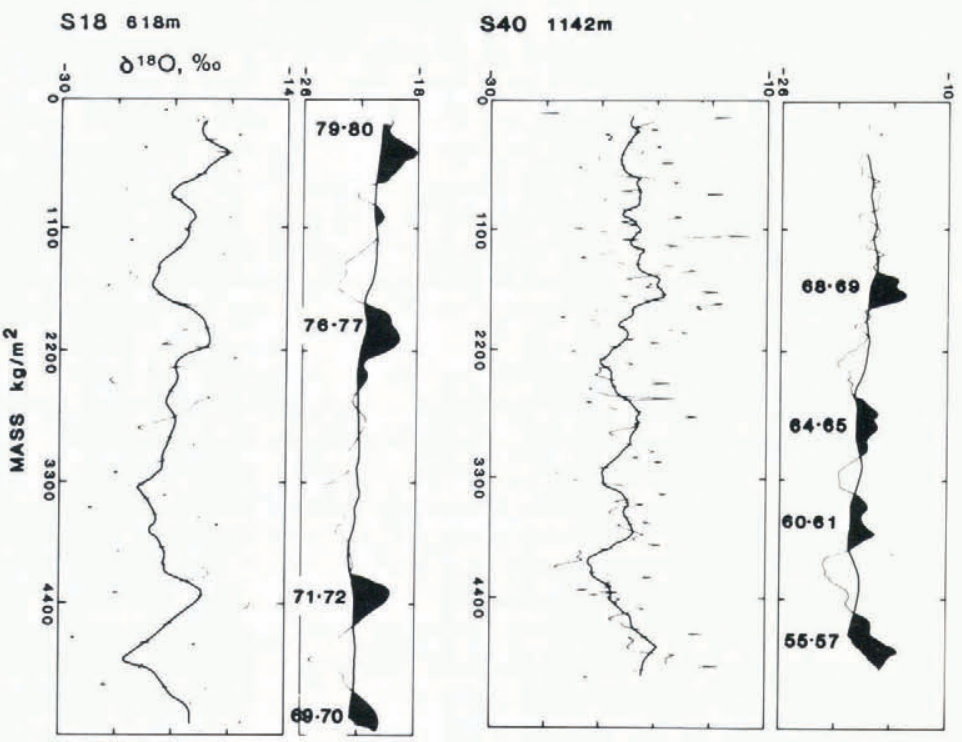

H128 $1380 \mathrm{~m}$

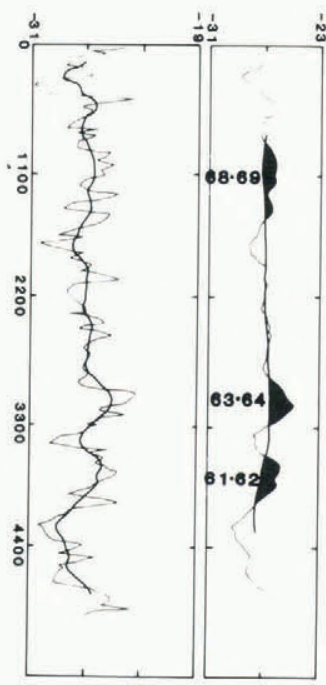

W200 $2168 \mathrm{~m}$

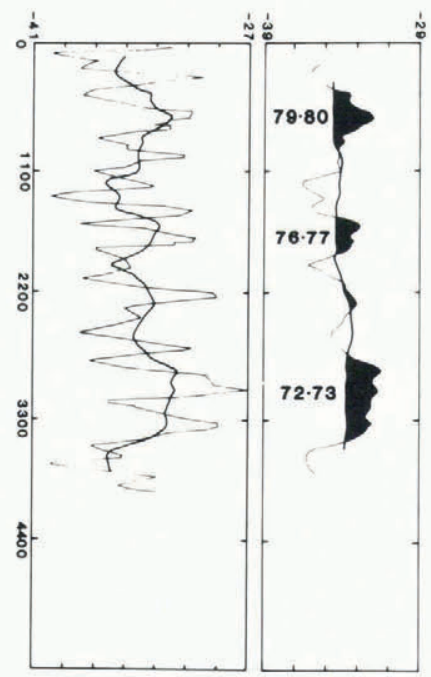

Fig. 3 a

Fig.3. Oxygen-isotope profile of $10 \mathrm{~m}$ long cores. The vertical axis is the cumulative mass of water equivalent of the core $\left(\mathrm{kg} / \mathrm{m}^{2}\right)$. $\delta^{18} \mathrm{O}$ data interval is $12-25 \mathrm{~kg} / \mathrm{m}^{2}$. Left-hand column: the thin line shows original data and the thick line is the running mean of ten results. Right-hand column: thin and thick lines are the running means of ten results and 50 results respectively. (a) Cores from the coastal region. Dates have been estimated from the oxygen-isotope stratigraphy. The dates of the top of each core are as follows: S18 (August 1981), S40 (February 1975), H128 (January 1973), and W200 (March 1981). (b) Cores from a typical katabatic region. Vertical lines in the upper layers of the Y100 and Y200 cores are estimated annual boundaries. Thick arrows indicate gross $\beta$ dating horizons. The dates of the top of each core are as follows: S122 (January 1973), Y100 (October 1981), and Y200 (October 1981). 
S122 $1910 \mathrm{~m}$

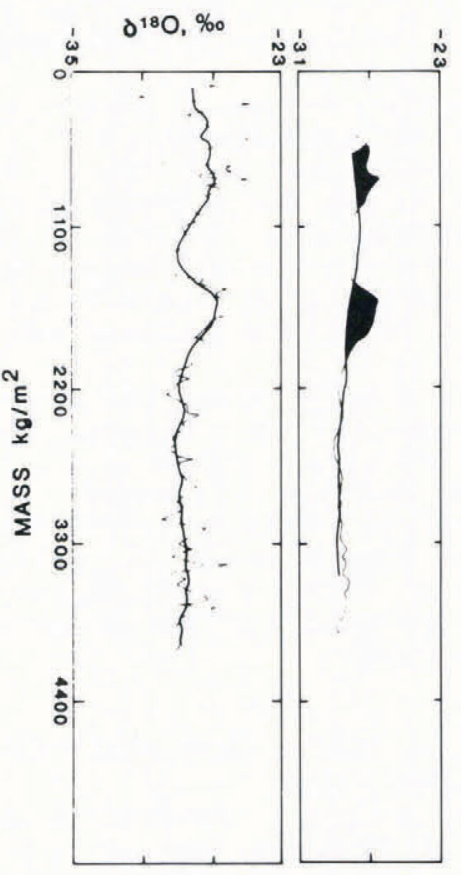

Fig. 3b
Y $1002606 \mathrm{~m}$

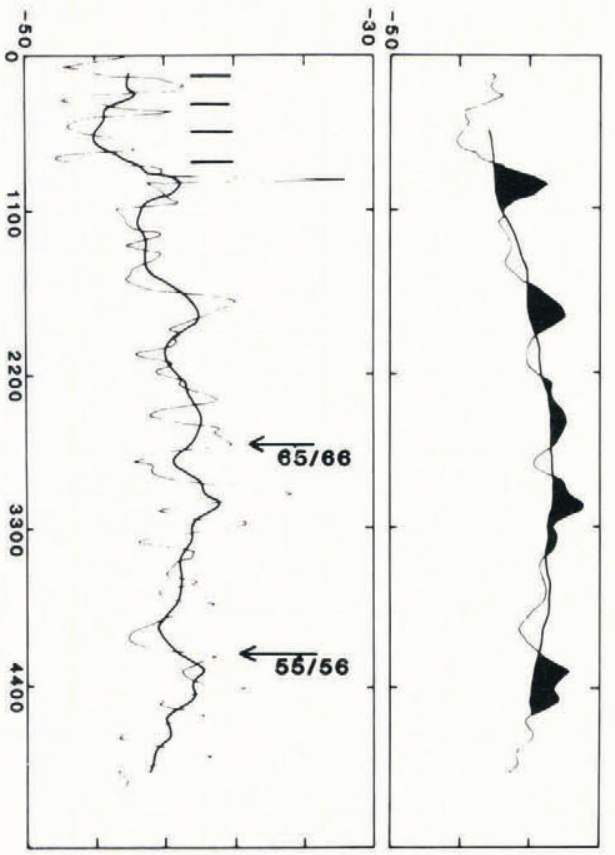

gross $\beta$ horizon
Y200 2880m

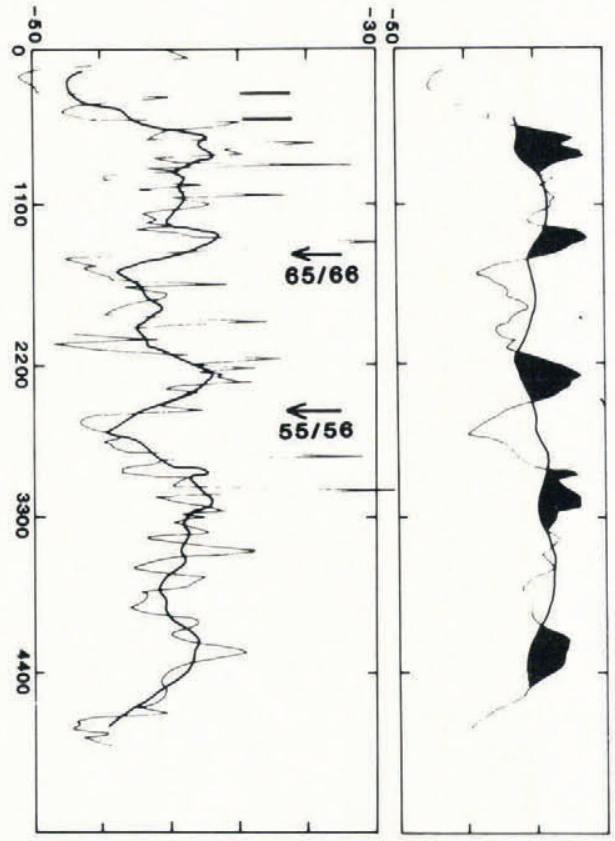

Direct comparison of the annual accumulation between route $\mathrm{H}-\mathrm{Z}$ and route $\mathrm{Y}$ presents some statistical problems, due to differences in the period of observation ( 1 year on route $\mathrm{Y}$, up to an average of 12 years on routes $\mathrm{H}$ and $\mathrm{Z}$ ). A tendency to increase slightly inland along route $\mathrm{Y}$ is found. The average values are $16 \mathrm{~cm}$ of snow between Mizuho Station and Y100, and $18 \mathrm{~cm}$ of snow between $\mathrm{Y} 100$ and $\mathrm{Y} 200$, corresponding to 6.0 and $6.7 \mathrm{~g}$ water equivalent, using a mean density of $377 \mathrm{~kg} \mathrm{~m}^{-3}$ which was obtained from surface snow cover along routes $\mathrm{S}, \mathrm{H}$, and $\mathrm{Z}$ (Nishio 1978).

\section{$\mathrm{S} 18(30 \mathrm{~m}$ core $)$}

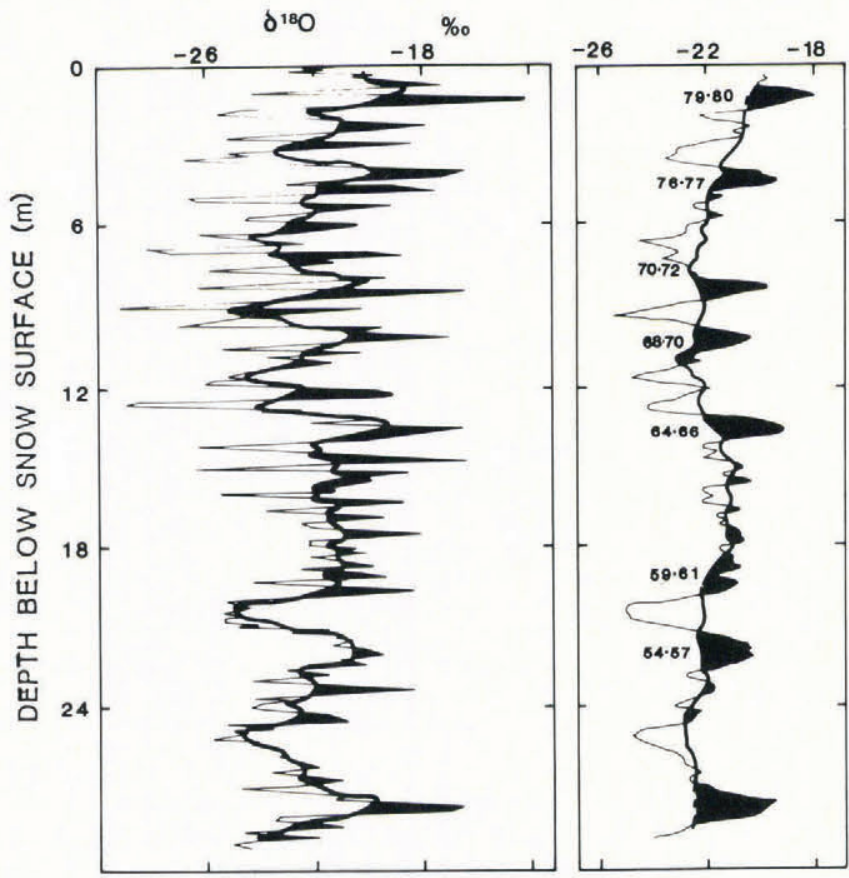

Fig.4. Oxygen-isotope data from a $30 \mathrm{~m}$ long core at $\mathrm{S} 18$. Data interval is $3-5 \mathrm{~cm}$ snow thickness. Left-hand column: original $\delta^{18} \mathrm{O}$ data and running means of ten results. Right-hand column: running means of ten results and 50 results respectively. The figures indicate the estimated dates at depth.
In estimating the accumulation rate, the hiatus of snow accumulation (leading to missing annual layers) should be taken into account. As shown in Figure 2a, negative and zero values are frequent along routes $\mathrm{Z}$ and $\mathrm{Y}$.

According to the stake measurements during 1972 and 1974 on route $\mathrm{Z}(1910-2230 \mathrm{~m}$ a.s.1.), the annual frequency of the hiatus is $13-45 \%$, in contrast to $1-7 \%$ below $1900 \mathrm{~m}$ a.s.1. The percentage is the ratio of the number of stakes which showed negative values of annual accumulation to the total number of stakes set up along the routes.

From consideration of the data from route $I-M$, the wave-like cyclic distribution suggests the existence of a migrating process in the preferred accumulation area.

\section{Oxygen-isotope profiles}

Core profiles in the coastal region

Up to the present, profiles showing the typical cyclic seasonal $\delta^{18} \mathrm{O}$ variation have been taken at $\mathrm{S} 18(618 \mathrm{~m}$ a.s.1.), point no. 1 on route $S$ of Figure 1 , where the annual net accumulation was assumed to be about $0.5-1.2 \mathrm{~m}$ snow per year. The profile to $30 \mathrm{~m}$ depth is shown in Figure 4. $\delta^{18} \mathrm{O}$ was analyzed on $3-5 \mathrm{~cm}$ thick layers $\left(12-25 \mathrm{~kg} / \mathrm{m}^{2}\right.$ in water equivalent), extending continuously through the entire depth. More than 30 annual layers were distinguished by the seasonal isotopic cycle, together with stratigraphic seasonal indicators such as melting phenomena. Using these year-by-year data, periods of less negative $\delta$ value deviations (dark part), shown as a difference between running means of 50 results and ten results, were estimated; they are shown in the right-hand column of Figure 4 . The accuracy of age determination above $20 \mathrm{~m}$ depth may be about 1-2 years, due to less frequent occurrence of missing annual layers in the heavy snow-accumulation area; the accuracy at lower depths is worse, due to stratigraphic disturbances caused by melting.

In comparison with periods of less negative $\delta$ value deviation in the profiles at S40, H128, and W200 in Figure $3 \mathrm{a}$, good agreement is found. The deviations may be useful for age determination.

\section{Core profiles in the typical katabatic region}

On a typical katabatic slope ranging from $1700-1900 \mathrm{~m}$ to $3000-3200 \mathrm{~m}$ a.s.1., dune formation by cyclone activity and sastrugi formation by stationary katabatic wind (deposition-erosion process) occur once or twice, at most, in a year at one place. It may be concluded that $\delta^{18} \mathrm{O}$ variations in the snow cover of a typical katabatic region depend on the season of deposition, and on the frequency 
and amount of accumulation in the year concerned. This means that the annual cycle of $\delta^{18} \mathrm{O}$ may not be found in this region.

Of three profiles of $10 \mathrm{~m}$ cores from the region shown in Figure $3 \mathrm{~b}$, the profile of $\mathrm{S} 122$ shows a straight general trend (running mean of 50 results) and less perturbation of original data, except in the upper few meters.

According to stratigraphic observation of this core, major development of depth hoar took place from just below the surface to a depth of $8 \mathrm{~m}$; below $2 \mathrm{~m}$ depth the grain-size was $>2 \mathrm{~mm}$ in diameter.

On this evidence, it seems that the area surrounding S122 has been subjected to a depositional regime with frequent occurrence of hiatus conditions and lower accumulation, resulting in the formation of less pronounced cyclic features in the $\delta^{18} \mathrm{O}$ profile.

On the other hand, larger fluctuations in general trends are typical features in the Y100 and Y200 profiles.

In these cores, a few annual layers in the uppermost part can be distinguished by stratigraphic interpretation. Judging from these results, annual accumulation under present conditions at both sites seems to fit the general trend of annual mean accumulation which is indicated in Figure 2. A very different mean accumulation rate for the period 1965/66-1980, for both cores, was obtained by using gross $B$ activity dating. One possibility is that the area of Y200 was subjected to hiatus conditions up to a few years ago. This may also have resulted in frequent displacement towards less negative $\delta^{18} \mathrm{O}$ values, towards the right of the $\delta^{18} \mathrm{O}$ profile.

For comparison with regional characteristics of $\delta^{18} \mathrm{O}$ profiles in surface cores, a power-spectrum analysis of the oxygen-isotope profile versus water equivalent of $10 \mathrm{~m}$ snow depth in Figure $3 \mathrm{a}$ and $\mathrm{b}$ was examined by applying the maximum-entropy method (MEM) developed by J.P. Burg (Hino 1977).
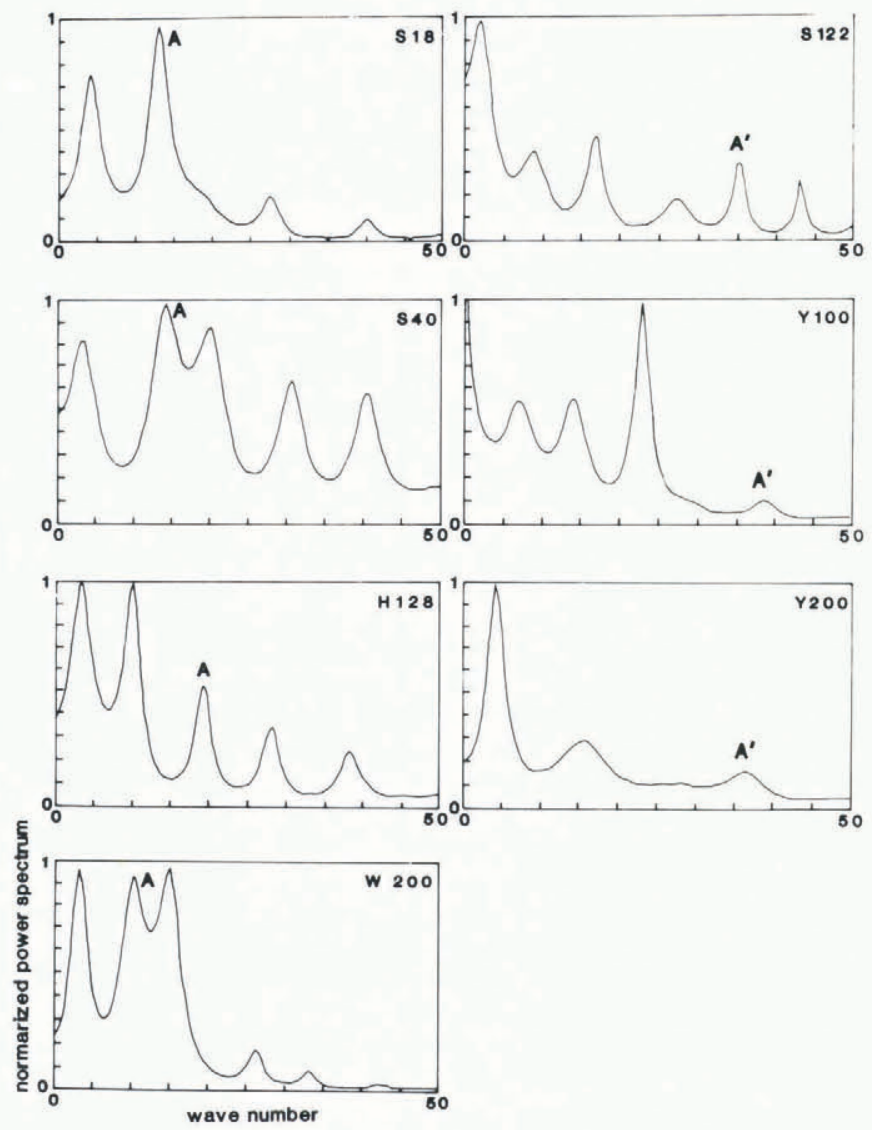

Fig.5. Power spectrum of $\delta^{18} \mathrm{O}$ profiles versus water equivalent for $10 \mathrm{~m}$ firn cores in the region from Mizuho plateau to the coast. The horizontal axis shows frequencies where a $10 \mathrm{~m}$ core length is 1 cycle. The vertical axis shows relative power spectrum where the maximum power value is 1 in each core. $A$ and $A^{\prime}$ : equivalent cycle to the accumulation value obtained from stake measurement.
In the power spectrum in Figure 5 (the left-hand column corresponds to Figure $3 \mathrm{a}$ and the right-hand column to Figure $3 \mathrm{~b}$ ), two or three prominent peaks are seen in the left-hand figures. "A" and " $\mathrm{A}$ " " in Figure 5 show the cycle which is equivalent to the estimated value of annual accumulation. The contrast in the power-spectrum peaks between the two groups, on the left and the right, may indicate the regional characteristics of the oxygen-isotope profile.

In general, predominant cycles correspond roughly to the estimated accumulation rate ("A" in Figure 5) in the coastal high-accumulation region; such evident correspondences are not found in the typical katabatic region.

\section{CONCLUDING REMARKS}

The main purpose of this study is to clarify the depositional regime of the typical katabatic slope of Mizuho plateau, in the light of annual snow accumulation and isotope distribution in the snow cover.

The regional trend of annual snow accumulation was obtained from stake observations made during 1968 and 1983. Annual layers in the cores obtained from various places on Mizuho plateau were also determined. A comparison of accumulation rate from stake measurements and estimated value by core analysis does not show large differences in the coastal region. In the typical katabatic region, on the other hand, the high occurrence of hiatus phenomena should be emphasized in dating. The general trend of the annual accumulation rate in the inland region (above 1700-1900 $\mathrm{m}$ a.s.l.) is found to range between 6 and $7 \mathrm{~g} \mathrm{year}^{-1}$, with larger scattering. When this trend value is applied to the interpretation of core dating in the long-term, some proportion of hiatus occurrence, at least $10-30 \%$, should be allowed for.

For climatic interpretation of deviation from the standard mean ocean water (SMOW) level in the $\delta^{18} \mathrm{O}$ profile, secular variations in surface accumulation in the coastal area were examined (Satow 1985). The deviation of the annual mean accumulation in the area is shown in Figure 6. Some similarities in appearance, such as the correspondence between the years of positive deviation (1970 and 1977) in Figure 6 and the larger deviation in less negative $\delta^{18} \mathrm{O}$ values in Figure 4 are found. A climatic explanation for this agreement has not been found.

Finally, all the isotope data for the snow cover are plotted versus distance from the coast in Figure 7 . The relation between the mean $5^{18} \mathrm{O}$ value and the distance can be expressed numerically as follows:

$$
f(x)=7.52 x^{0.29}
$$

where $f(x)$ is the mean $\delta^{18} O$ value at the place (- $\left.-x_{0}\right)$ and $\mathrm{X}$ is distance $(\mathrm{km})$ from the coast. The standard deviation is $2.74 \%$ and a good coefficient of determination $(0.97)$ is obtained. This relation may be useful for estimating the original point of deposition of a layer in an ice core, assuming constant climatic conditions.

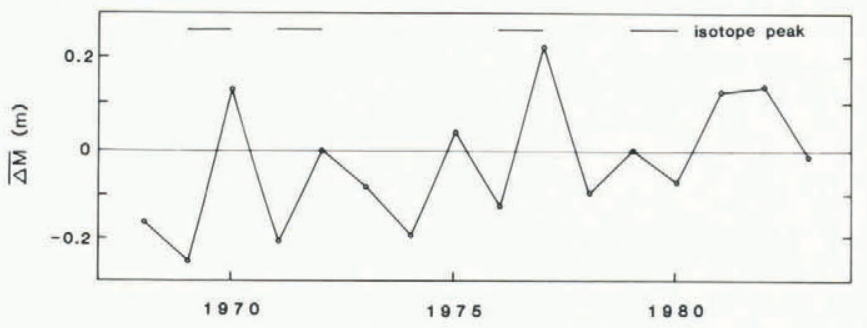

Fig.6. Deviation (in meters) of the annual mean net accumulation in the coastal region, Mizuho plateau. $\Delta \mathrm{M}$; The standard deviation from the annual mean net accumulation at a site. $\Delta \mathrm{M}$ : average of $\Delta \mathrm{M}$ at about 80 sites in the area. 


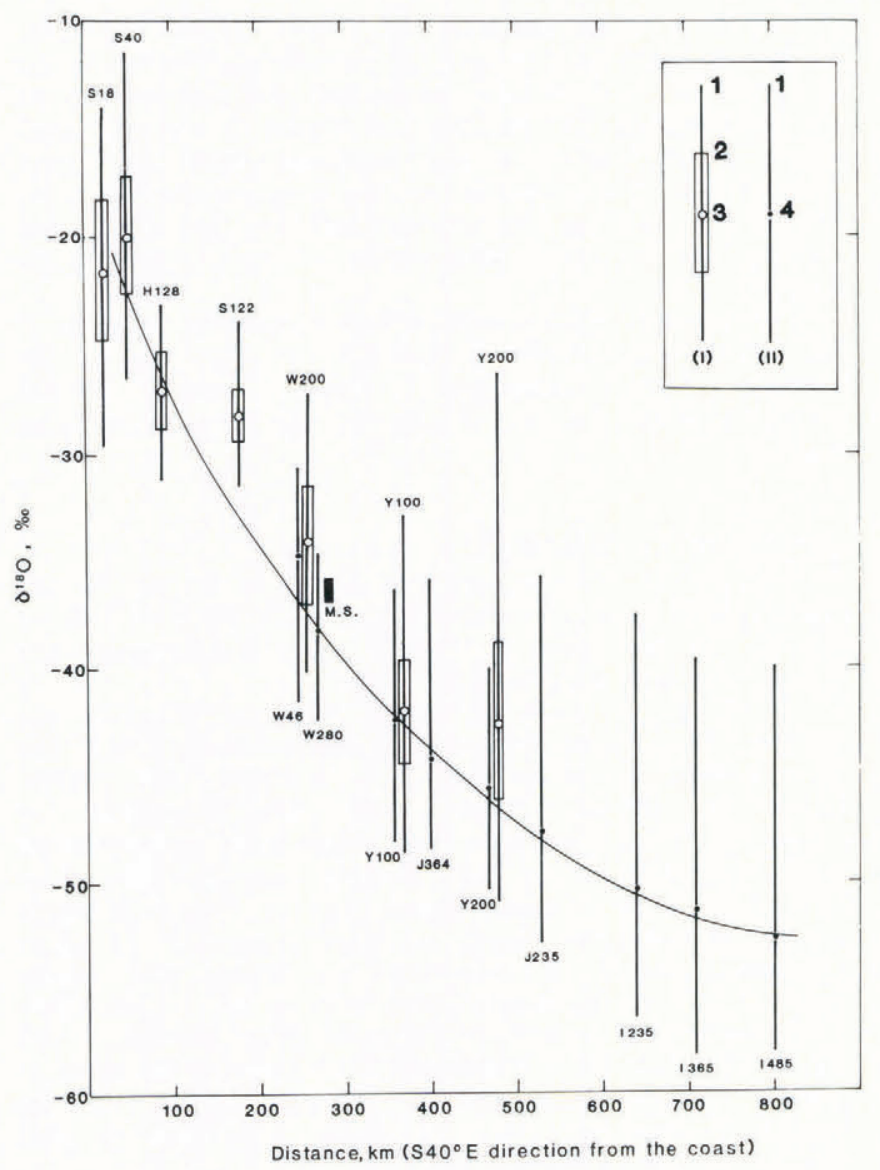

Fig.7. Relation between $\delta^{18} \mathrm{O}$ value and distance from the coast. (I) data from $10 \mathrm{~m}$ long core; (II) data from $2 \mathrm{~m}$ pit. $\delta^{18} \mathrm{O}$ values are plotted as follows: (1) range of whole $\delta^{18} \mathrm{O}$ value, (2) range of standard deviation, (3) and (4) simple mean value. M.S.: $\delta^{18} \mathrm{O}$ annual range of falling snow at Mizuho Station.

\section{REFERENCES}

Hino M 1977 Spectral analysis. Tokyo, Asakura Shoten [In Japanese]

Naruse R, Shimizu H 1978 Flow line of the ice sheet over Mizuho Plateau. Memoirs of National Institute of Polar Research. Special Issue 7: 227-234

Nishio F 1978 Glaciological survey in 1976-1977. Density of surface snow along Routes $\mathrm{S}, \mathrm{H}$ and $\mathrm{Z}$. JARE Data Report 44: 118-121

Satow K 1985 Variability of surface mass balance in the Mizuho Plateau, Antarctica. Memoirs of National Institute of Polar Research. Special Issue 39: 132-140

Satow K, Watanabe O 1985 Net accumulation and oxygen isotope composition of snow on Mizuho Plateau, Antarctica. Annals of Glaciology 6: 300-302

Shimizu H, Watanabe $O$, Kobayashi S, Yamada $T$, Naruse R, Ageta Y 1978 Glaciological aspects and mass budget of the ice sheet in Mizuho Plateau. Memoirs of National Institute of Polar Research. Special Issue 7: 264-274

Watanabe O 1978[a] Distribution of surface features of snow cover in Mizuho Plateau. Memoirs of National Institute of Polar Research. Special Issue 7: 44-62

Watanabe O 1978[b] Stratigraphic studies of the snow cover in Mizuho Plateau. Memoirs of National Institute of Polar Research. Special Issue 7: 154-181 